\title{
Simple and rapid HPLC-UV methods for gabapentin quantification in human plasma and urine: applicability in pharmacokinetics and drug monitoring
}

\author{
Priscila Akemi Yamamoto ${ }^{1,2}$ (1), Jhohann Richard de Lima Benzi ${ }^{2}$ (1), Natália Valadares de Moraes ${ }^{1 *}$ (1) \\ 'Departamento de Fármacos e Medicamentos, Faculdade de Ciências Farmacêuticas, Universidade Estadual Paulista "Júlio de \\ Mesquita Filho" (UNESP), Araraquara, SP, Brasil \\ ${ }^{2}$ Departamento de Análises Clínicas, Toxicológicas e Bromatológicas, Faculdade de Ciências Farmacêuticas de Ribeirão Preto, \\ Universidade de São Paulo (USP), Ribeirão Preto, SP, Brasil
}

*Corresponding author: natalia.v.moraes@unesp.br

\begin{abstract}
Aim: We aimed to develop methods to determine gabapentin (GAB) in biological samples using high-performance liquid chromatography (HPLC) with application in pharmacokinetics and therapeutic drug monitoring. Methods: Simple, rapid and efficient HPLC-UV methods to quantify $G A B$ in human plasma and urine were developed and validated for clinical analysis of GAB. The 1fluoro-2,4-dinitrobenzene (FDNB) was used as derivatization agent. For plasma samples, protein precipitation using acetonitrile was performed, before the derivatization reaction. Urine samples were cleaned-up by liquid-liquid extraction with dichloromethane:n-butanol $(1: 1, \mathrm{v} / \mathrm{v})$ after derivatized. Amlodipine besilate was used as internal standard (IS). Results: Gabapentin and IS were resolved on LiChrospher ${ }^{\circledR}$ C 18 RP column and a mixture of $50 \mathrm{mM}$ sodium phosphate buffer ( $\mathrm{pH}$ 3.9):methanol (27:73, v/v) as mobile phase, at $1.2 \mathrm{~mL} / \mathrm{min}$. The methods used small sample volumes, 100 and $50 \mu \mathrm{L}$ of plasma and urine, respectively. Linearity was obtained in the interval of $0.2-14 \mu \mathrm{g} / \mathrm{mL}$ in plasma and $2-120 \mu \mathrm{g} / \mathrm{mL}$ in urine. Both methods showed to be selective, without carry-over effect, precise, accurate and stable in different conditions. GAB plasma concentration in patients receiving 600 to $3600 \mathrm{mg}$ /day of GAB ranged between 0.40 to 11.94 $\mu \mathrm{g} / \mathrm{mL}$ at steady-state. Conclusions: The methods described in this study were simple, rapid and fulfill all validation requirements. They were easily and successfully applied for population pharmacokinetics and therapeutic drug monitoring of GAB in patients with chronic pain.
\end{abstract}

Keywords: Gabapentin. HPLC. Plasma. Urine.

\section{How to cite}

Yamamoto PA, Benzi JRL, Moraes NV. Simple and rapid HPLC-UV methods for gabapentin quantification in human plasma and urine: applicability in pharmacokinetics and drug monitoring. Rev Ciênc Farm Básica Apl. 2021;42: e717. https://doi.org/10.4322/2179-443X.0717

Funding support: PAY - received scholarship from CAPES (Coordenação de Aperfeiçoamento de Pessoal de Nível Superior - Finance Code 001). JRLB received scholarship from FAPESP (Fundação de Amparo à Pesquisa do Estado de São Paulo - 2015/25728-2). NVM - received financial support from PADC (Programa de Apoio ao Desenvolvimento Científico - PADC-FCF, UNESP). The complementary information will be provided by the authors upon justified request.

Conflicts of interest: PAY, JRL, NVM no conflict of interest.

O estudo foi realizado na Faculdade de Ciências Farmacêuticas, Universidade Estadual Paulista "Júlio de Mesquita Filho"

(UNESP), Araraquara, SP, Brasil.

Received on December 18, 2020. Accepted on February 17, 2021. 


\section{INTRODUCTION}

Pain is considered a public health problem ${ }^{1}$. In 2019, around $20 \%$ of adults reported chronic pain in the past 3 months in the U.S., according to the National Health Interview Survey $^{2}$. In the Brazilian population the prevalence of chronic pain varied between 29.3 to $73.3 \%^{3}$. Neuropathic pain is one of the seven categories of chronic pain in the International Classification of Diseases (ICD-11). The number of people affected by neuropathic pain should increase even more due to the increase of elderly population, diabetes incidence and higher survival from cancer ${ }^{4}$.

Gabapentin (GAB) is recommended as first-line treatment for various neuropathic pain conditions (e.g. diabetic neuropathic pain, postherpetic neuralgia, central pain) ${ }^{5}$. For patients with hepatic dysfunction GAB is possibly the safest choice because it is not metabolized, does not bind to plasma proteins and is mainly eliminated unchanged in urine ${ }^{6-8}$. Although GAB is widely prescribed (in 2019, 69 million GAB prescription were dispensed in U.S.), its therapeutic drug monitoring (TDM) is not usual in clinical practice ${ }^{9}$. TDM can be applied when a reference target of plasma concentrations associated with drug efficacy and minimal risk of adverse events is available. In the context of drugs to treat neuropathic pain, TDM can be also a tool to monitor patient adherence, to help physicians decide the best treatment for the patient and to avoid unnecessary opioid prescription. Opioids are the third-line treatment for neuropathic pain, but show high risk of addiction ${ }^{5,10}$.

There are several high-performance liquid chromatography (HPLC) methods to quantify GAB plasma concentration using UV-vis (HPLC-UV) ${ }^{11-15}$ and fluorescence (HPLC-FLD) detection ${ }^{16-21}$. However, they use high plasma volume ${ }^{12,15}$, did not fulfill full validation requirements or present the method validation ${ }^{13,14,16-19}$. This study aimed to develop and validate simple, rapid and efficient bioanalytical methods using small sample volume to quantify GAB in human plasma and urine by HPLC-UV with appropriate concentrations range to use in clinical analysis of GAB in patients with chronic pain.

\section{METHODS}

\section{Chemical and reagents}

Gabapentin certificate standard (GAB, 99.8\%, USP Reference Standard, Rockville, MD, USA) and amlodipine besylate (99.7\%, EDQM, Strasbourg, France) were purchased from LAS do Brasil (Aparecida de Goiânia, Brasil) and Sigma Aldrich ${ }^{\circledR}$ (São Paulo, Brazil), respectively. 1-fluoro-2,4-dinitrobenzene (FDNB) was used as derivatization agent. The solvents methanol (J.T. Baker, Ecatepec, México), acetonitrile (J.T. Baker, Ecatepec, México), dichloromethane (Sigma-Aldrich, St. Louis, USA), n-butanol (Sigma-Aldrich, Duque de Caxias, Brasil) were HPLC grade. The reagents sodium phosphate monobasic (Synth, Diadema, Brazil), 85\% o-phosphoric acid (Synth, Diadema, Brazil), 37\% chloridric acid (Qhemis, Brazil), boric acid (Sigma, St. Louis, MO, USA), sodium hydroxide (Audaz, São Paulo, Brazil) and potassium chloride (Amresco, Solon, OH, USA) were of analytical grade. Water was obtained from the Milli-Q Plus purification system (Millipore, Belford, MA, USA).

\section{Standard and reagents solutions and quality control samples}

Stock solutions of GAB for plasma and urine analysis were prepared in methanol at 100 and $1000 \mu \mathrm{g} / \mathrm{mL}$, respectively. The work solutions were prepared at concentrations of 1,2 , $5,10,20,30,60$ and $70 \mu \mathrm{g} / \mathrm{mL}$ in methanol for plasma. For urine the concentrations were 5 , $10,20,30,50,75,100,150,200$ and $300 \mu \mathrm{g} / \mathrm{mL}$ in methanol. The standard solutions were 
stored at $-20^{\circ} \mathrm{C}$. Amlodipine besylate, used as internal standard (IS), was prepared at concentration of $200 \mu \mathrm{g} / \mathrm{mL}$ in water and stored at $4-8^{\circ} \mathrm{C}$. The stock solution of $0.06 \mathrm{M}$ FDNB was prepared in acetonitrile and stored at $4-8^{\circ} \mathrm{C}$.

Quality control (QC) samples were blank samples (biological matrix without GAB and IS) spiked with $G A B$ standard solution independently from the calibration standards. Five concentration levels ( $\mu \mathrm{g} / \mathrm{mL}$ in plasma-urine, respectively) were used: lower limit of quantification (LLOQ, 0.2-2), low QC (LQC, 0.4-4), medium QC (MQC, 6-60), high QC (HQC, 11-90) and QC of dilution integrity (DQC, 20-300).

\section{HPLC method}

GAB concentration was analyzed using a Shimadzu liquid chromatograph (Kyoto, Japan) composed by LC-20AT quaternary pump system, DGV-20A4R degasser and SDP-20AT UVVIS detector. Gabapentin and IS were resolved on LiChrospher ${ }^{\circledR}$ C18 RP $(125 \times 4 \mathrm{~mm}, 5 \mu \mathrm{m}$; Merck, Darmstadt, Germany) column with LiChroCART ${ }^{\circledR}$ 4-4 Purospher $^{\circledR}$ RP-18 capped guard-column ( $5 \mu \mathrm{m}$; Merck, Darmstadt, Germany), kept at room temperature. The mobile phase was consisted of $50 \mathrm{mM}$ sodium phosphate buffer ( $\mathrm{pH} 3.9)$ :methanol $(27: 73, \mathrm{v} / \mathrm{v})$, at $1.2 \mathrm{~mL} / \mathrm{min}$. Detection was performed at the wavelength of $360 \mathrm{~nm}$. Data acquisition and sample quantification were performed using LabSolutions software, version 5.57 SP1 (Shimadzu Inc., Kyoto, Japan).

\section{Plasma sample preparation}

Sample preparation was performed according to Jalalizadeh et al. (2007), with some modifications to reduce the volume of plasma samples and keep it simple ${ }^{13}$. Briefly, $100 \mu \mathrm{L}$ of plasma were added with $25 \mu \mathrm{L}$ of IS solution. For protein precipitation, $200 \mu \mathrm{L}$ of acetonitrile were added, mixed for $5 \mathrm{~min}$ and centrifuged for $15 \mathrm{~min}\left(15000 \times \mathrm{g}, 24^{\circ} \mathrm{C}\right)$. The supernatant $(200 \mu \mathrm{L})$ was removed to a clean tube and $200 \mu \mathrm{L} 0.25 \mathrm{M}$ borate buffer $(\mathrm{pH}$ 8.2), $30 \mu \mathrm{L} 0.06 \mathrm{M}$ FDNB and $1 \mathrm{~mL}$ acetonitrile were added. The mixture was inverted, kept in dark in a dryer block at $65^{\circ} \mathrm{C}$ for $10 \mathrm{~min}$ for derivatization reaction.

After derivatization, samples were kept at room temperature for 5 min and $25 \mu \mathrm{L} 1 \mathrm{M} \mathrm{HCl}$ solution were added. Samples were inverted and evaporated up to dryness. Residues were reconstituted in $200 \mu \mathrm{L}$ of mobile phase and $50 \mu \mathrm{L}$ were injected.

\section{Urine sample preparation}

Samples of $50 \mu \mathrm{L}$ of urine were added with $25 \mu \mathrm{L}$ of IS solution, $60 \mu \mathrm{L} 0.25 \mathrm{M}$ borate buffer (pH 8.2), $10 \mu \mathrm{L} 0.06 \mathrm{M}$ FDNB and $300 \mu \mathrm{L}$ acetonitrile. Derivatization reaction was performed in the same conditions described for plasma samples. Then, liquid-liquid extraction using $500 \mu \mathrm{L}$ of dichloromethane:n-butanol $(1: 1, \mathrm{v} / \mathrm{v})$ mixture was used as clean-up method. Samples were shaken for $20 \mathrm{~min}$ and centrifuged for $15 \mathrm{~min}\left(15000 \times \mathrm{g}, 24^{\circ} \mathrm{C}\right)$. Organic phase $(750 \mu \mathrm{L}$ ) was separated and evaporated up to dryness. Residues were reconstituted ( $200 \mu \mathrm{L}$ mobile phase) and analyzed (50 $\mu \mathrm{L})$.

\section{Method validation}

Full validation was performed according to the "Guideline on Bioanalytical Method Validation" by European Medicines Agency ${ }^{22}$. The LLOQ was determined by analyzing samples spiked with 0.1 or $0.2 \mu \mathrm{g}$ of $\mathrm{GAB} / \mathrm{mL}$ plasma; and 2 or $4 \mu \mathrm{g}$ of $\mathrm{GAB} / \mathrm{mL}$ urine. Selectivity was performed with six blank plasma and twelve blank urine sources. Carryover effect was verified by injecting three samples of blank plasma/urine, one before and 
two immediately after the injection of two samples at the upper limit of quantification (ULOQ).

Linearity was evaluated with three calibration curves including the blank sample, zero sample (biological matrix spiked only with IS) and blank samples spiked with GAB standard solution and IS to reach the final concentrations of $0.2,0.4,1,2,4,6,12,14 \mu \mathrm{g} / \mathrm{mL}$ of $\mathrm{GAB}$ in plasma and $2,4,8,12,20,30,40,60,80$ and $120 \mu \mathrm{g} / \mathrm{mL}$ of $\mathrm{GAB}$ in urine. A linear mathematical model using the weight $1 / x^{2}$ was applied.

Accuracy and precision, within-run (single run) and between-run (three different runs), were determined as described by EMA ${ }^{22}$. Five replicates of each QC samples were analyzed. Accuracy was expressed as relative error (RE, \%, Equation 1), the concentration obtained by the method should be within $15 \%$ of the nominal concentration value, except for the LLOQ for which values within $20 \%$ of the nominal concentration are accepted.

$$
R E=\frac{(\text { observed mean concentration }- \text { nominal concentration })}{\text { nominal concentration }} \times 100
$$

The precision was expressed as the coefficients of variation (CV, \%, Equation 2). The CV values should not exceed $15 \%$, except for the LLOQ for which CV values within $20 \%$ are accepted.

$$
C V=\frac{\text { standard deviation }}{\text { meanconcentration }} \times 100
$$

Stability of GAB in plasma and urine samples was assessed using a triplicate of the LQC and HQC. All stability determinations used a freshly prepared calibration curve to obtain the sample concentrations. The stability has been demonstrated in the following conditions: (a) short-term stability at room temperature for $6 \mathrm{~h}$; (b) post-preparative stability for $24 \mathrm{~h}$ at room temperature; (c) after 3 cycles of freeze $\left(-70^{\circ} \mathrm{C}\right)$ and thaw; (d) long-term stability at $70^{\circ} \mathrm{C}$; (e) stock and working standard solutions of GAB stored for 120 days at $-20^{\circ} \mathrm{C}$ and IS solution stored for 30 days at $4-8^{\circ} \mathrm{C}$.

\section{Applicability of the method}

The methods were applied to population pharmacokinetics (PopPK) and TDM of GAB in patients receiving the same daily dose of GAB for at least 1 week (steady-state) ${ }^{23,24}$. The study was approved by the School of Pharmaceutical Sciences (FCF-CEP) Ethical Committee of UNESP (CAAE: 53902516.4.0000.5426) with accord of the Ethics Committee of HCFMRPUSP (CAAE: 53902516.4.3001.5440). Blood sample was collected at steady state and urine samples were collected between dose intervals, both were stored frozen at $-70{ }^{\circ} \mathrm{C}$ until analysis.

\section{RESULTS}

\section{Method validation}

In this study, the methods were selective (Figure 1) without residual effects (Figure 2). Linearity was obtained between $0.2-14 \mu \mathrm{g} / \mathrm{mL}$ plasma $\left(y=0.07957 x-0.00605, r^{2}=0.99257\right)$ and $2-120 \mu \mathrm{g} / \mathrm{mL}$ urine $\left(y=0.01088 x-0.00415, r^{2}=0.99741\right)$ concentrations using the weighting $1 / x^{2}$. 

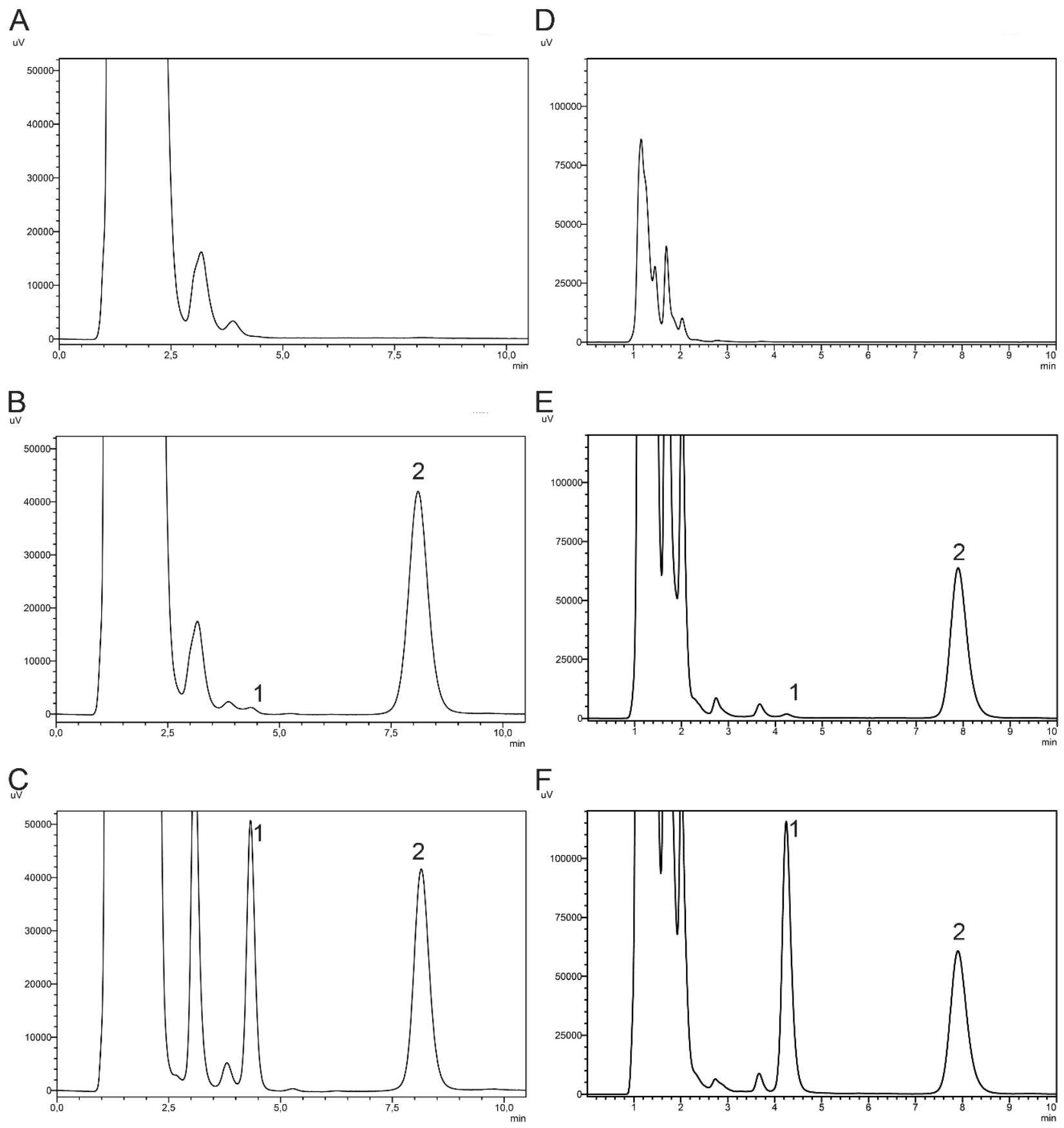

Figure 1. Chromatograms of gabapentin in plasma and urine by HPLC-UV. (A) Blank human plasma (B) Blank human plasma spiked with $0.2 \mu \mathrm{g}$ of $\mathrm{GAB} / \mathrm{mL}$ and internal standard (IS, $200 \mu \mathrm{g} / \mathrm{mL}$ ) (C) Patient plasma sample at steady-state spiked with IS (D) Blank human urine (E) Blank human urine spiked with $120 \mu \mathrm{g}$ of $\mathrm{GAB} / \mathrm{mL}$ and IS (F) Patient urine sample spiked with IS. [Peak: 1. Gabapentin, 2. Amlodipine (IS)].

Precision and accuracy were within 15\% coefficient of variation and relative error, respectively. Five- and ten-fold dilutions of plasma and urine samples, respectively, did not affect the accuracy and precision (Table 1).

Stability determinations indicated that samples were stable for up to $6 \mathrm{~h}$ at room temperature (short-term stability) and after three cycles of freeze $\left(-70^{\circ} \mathrm{C}\right)$ and thaw (room temperature). Plasma samples were stable after stored for 120 days at $-70^{\circ} \mathrm{C}$. On the other hand, urine sample did not show stability when stored for 60 days at $-70^{\circ} \mathrm{C}$. The stock and working standard solutions of GAB were stable for 120 days when stored at $-20^{\circ} \mathrm{C}$ (Table 2). 

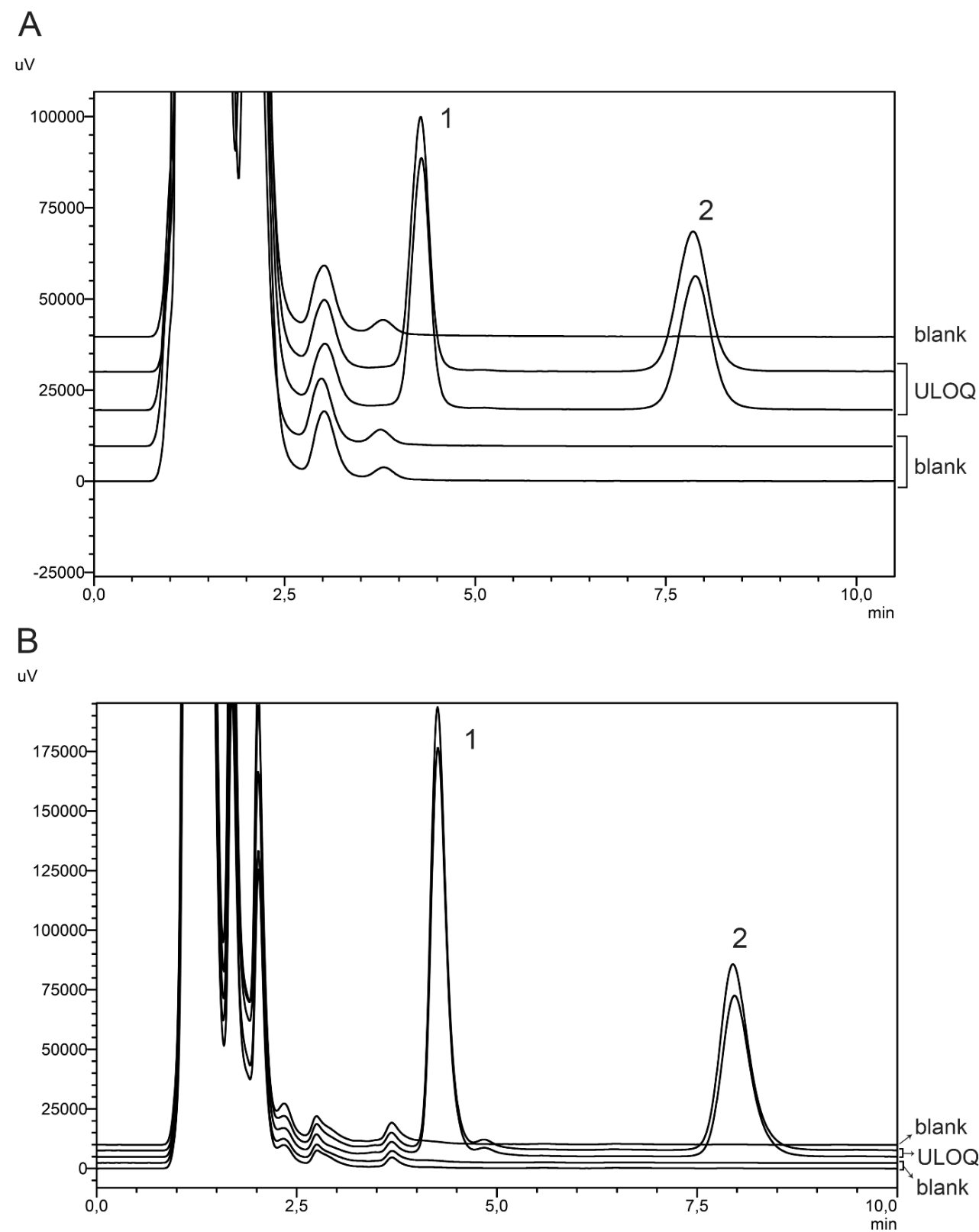

Figure 2. Carry-over effect evaluation on plasma (A) and urine (B). ULOQ: upper limit of quantification (14 and $120 \mu \mathrm{g} / \mathrm{mL}$ of plasma and urine, respectively). Blank: matrix without GAB and IS. [Peak: 1. Gabapentin, 2. Amlodipine (IS)].

Table 1. Precision and accuracy of HPLC-UV methods for the analysis of gabapentin in human plasma and urine

\begin{tabular}{|c|c|c|c|c|}
\hline & \multicolumn{2}{|c|}{ Concentration } & \multirow{2}{*}{$\begin{array}{l}\text { Precision } \\
\text { CV (\%) }\end{array}$} & \multirow{2}{*}{$\begin{array}{c}\text { Accuracy RE } \\
(\%)\end{array}$} \\
\hline & $\begin{array}{l}\text { Nominal } \\
(\mu \mathrm{g} / \mathrm{mL})\end{array}$ & $\begin{array}{c}\text { Observed } \\
(\text { mean } \pm \text { SD) }\end{array}$ & & \\
\hline \multicolumn{5}{|l|}{ Plasma } \\
\hline \multirow[t]{5}{*}{ Within-run $(n=5)$} & LLOQ (0.2) & $0.21 \pm 0.01$ & 6.24 & 3.37 \\
\hline & LQC (0.4) & $0.42 \pm 0.02$ & 4.33 & 5.54 \\
\hline & MQC (6) & $6.8 \pm 0.06$ & 0.90 & 13.31 \\
\hline & HQC (11) & $12.48 \pm 0.64$ & 5.13 & 13.47 \\
\hline & DQC (20) & $19.79 \pm 1.06$ & 5.37 & -1.03 \\
\hline
\end{tabular}




\begin{tabular}{|c|c|c|c|c|}
\hline & \multicolumn{2}{|c|}{ Concentration } & \multirow{2}{*}{$\begin{array}{l}\text { Precision } \\
\text { CV (\%) }\end{array}$} & \multirow{2}{*}{$\begin{array}{c}\text { Accuracy RE } \\
(\%)\end{array}$} \\
\hline & $\begin{array}{l}\text { Nominal } \\
(\mu \mathrm{g} / \mathrm{mL})\end{array}$ & $\begin{array}{c}\text { Observed } \\
(\text { mean } \pm \text { SD })\end{array}$ & & \\
\hline \multirow[t]{5}{*}{ Between-run ( $n=3)$} & LLOQ (0.2) & $0.20 \pm 0.02$ & 9.89 & 1.69 \\
\hline & LQC (0.4) & $0.41 \pm 0.02$ & 4.35 & 2.55 \\
\hline & $\mathrm{MQC}(6)$ & $6.88 \pm 0.21$ & 3.03 & 14.71 \\
\hline & $\mathrm{HQC}(11)$ & $12.47 \pm 0.51$ & 4.07 & 13.32 \\
\hline & DQC (20) & $20.59 \pm 1.26$ & 6.13 & 2.95 \\
\hline \multicolumn{5}{|l|}{ Urine } \\
\hline \multirow[t]{5}{*}{ Within-run (n=5) } & LLOQ (2) & $2.06 \pm 0.09$ & 4.53 & 3.02 \\
\hline & LQC (4) & $3.45 \pm 0.11$ & 3.06 & -13.63 \\
\hline & MQC (60) & $53.77 \pm 3.67$ & 6.82 & -10.39 \\
\hline & HQC (90) & $82.47 \pm 2.34$ & 2.83 & -8.36 \\
\hline & DQC (300) & $281.10 \pm 14.51$ & 5.16 & -6.30 \\
\hline \multirow[t]{5}{*}{ Between-run $(n=3)$} & LLOQ (2) & $2.08 \pm 0.20$ & 9.74 & 4.15 \\
\hline & LQC (4) & $3.70 \pm 0.35$ & 9.45 & -7.60 \\
\hline & MQC (60) & $56.64 \pm 5.00$ & 8.83 & -5.61 \\
\hline & HQC (90) & $91.10 \pm 9.04$ & 9.92 & 1.23 \\
\hline & DQC (300) & $325.95 \pm 45.19$ & 13.86 & 8.65 \\
\hline
\end{tabular}

SD: standard deviation; CV: coefficient of variation [(SD/mean concentration) $\times 100]$; RE: relative error \{[(observed mean concentration - nominal concentration)/nominal concentration] x 100\}; LLOQ: lower limit of quantification; LQC: Iow quality control; MQC: medium quality control; HQC: high quality control; DQC: quality control for dilution integrity.

Table 2. Stability of gabapentin in plasma, urine and solutions

\begin{tabular}{|c|c|c|c|c|}
\hline & \multicolumn{4}{|c|}{ RE, \% (n=3) } \\
\hline & Short-term & $\begin{array}{c}\text { Post- } \\
\text { processing }\end{array}$ & $\begin{array}{l}\text { Freeze-thaw } \\
\text { cycles }\end{array}$ & Long-term \\
\hline Plasma & $\left(6 h\right.$ at $\left.24^{\circ} \mathrm{C}\right)$ & $\left(24 h\right.$ at $\left.24^{\circ} \mathrm{C}\right)$ & $\left(3\right.$ cycles, $\left.-70^{\circ} \mathrm{C}\right)$ & $\left(120\right.$ days at $\left.-70^{\circ} \mathrm{C}\right)$ \\
\hline LQC $(0.4 \mu \mathrm{g} / \mathrm{mL})$ & 0.29 & -12.31 & 11.81 & -0.89 \\
\hline $\mathrm{HQC}(11 \mu \mathrm{g} / \mathrm{mL})$ & 9.65 & 11.09 & 10.34 & 6.55 \\
\hline Urine & $\left(6 h\right.$ at $\left.24^{\circ} \mathrm{C}\right)$ & $\left(24 h\right.$ at $\left.24^{\circ} \mathrm{C}\right)$ & $\left(3\right.$ cycles, $\left.-70^{\circ} \mathrm{C}\right)$ & (60 days at $-70^{\circ} \mathrm{C}$ ) \\
\hline LQC (4 Hg/mL) & 8.44 & 7.04 & -5.54 & $-20,21$ \\
\hline $\mathrm{HQC}(90 \mu \mathrm{g} / \mathrm{mL})$ & 0.09 & -0.73 & -4.22 & $-42,20$ \\
\hline \multicolumn{3}{|c|}{ Standard solutions } & \multicolumn{2}{|c|}{$R E, \%(n=3)$} \\
\hline \multicolumn{5}{|c|}{ Gabapentin $\left(120\right.$ days at $\left.-20^{\circ} \mathrm{C}\right)$} \\
\hline \multicolumn{3}{|c|}{ Working solution ( $1 \mu \mathrm{g} / \mathrm{mL}$ methanol) } & \multicolumn{2}{|c|}{9.48} \\
\hline \multicolumn{3}{|c|}{ Stock solution $(100 \mu \mathrm{g} / \mathrm{mL}$ methanol) } & \multicolumn{2}{|c|}{10.08} \\
\hline \multicolumn{5}{|c|}{ Amlodipine $\left(30\right.$ days at $4-8^{\circ} \mathrm{C}$ ) } \\
\hline \multicolumn{3}{|c|}{ Working solution ( $200 \mu \mathrm{g} / \mathrm{mL}$ water) } & \multicolumn{2}{|c|}{-2.24} \\
\hline \multicolumn{3}{|c|}{ Stock solution (400 $\mu \mathrm{g} / \mathrm{mL}$ water) } & \multicolumn{2}{|c|}{5.21} \\
\hline
\end{tabular}

RE: relative error $\{[($ observed mean concentration - nominal concentration)/nominal concentration] $\times 100\}$; LQC: low quality control; HQC: high quality control.

\section{Gabapentin quantification in patients with chronic pain}

The method was successfully applied for the analysis of GAB in plasma samples at steadystate. Trough plasma concentrations ranged between 0.40 to $11.94 \mu \mathrm{g} / \mathrm{mL}$ in patients treated with 600 to $3600 \mathrm{mg} /$ day, as reported previously ${ }^{24}$. 
Ten urine samples were collected in the intervals 0-12 $h(n=4)$ and 0-8 $h(n=6)$ after drug administration. The high interindividual variability observed in the amount of GAB eliminated unchanged in urine (Ae \%) in the dose interval can be explained, at least in part, by the variable bioavailability of GAB (Figure 3).

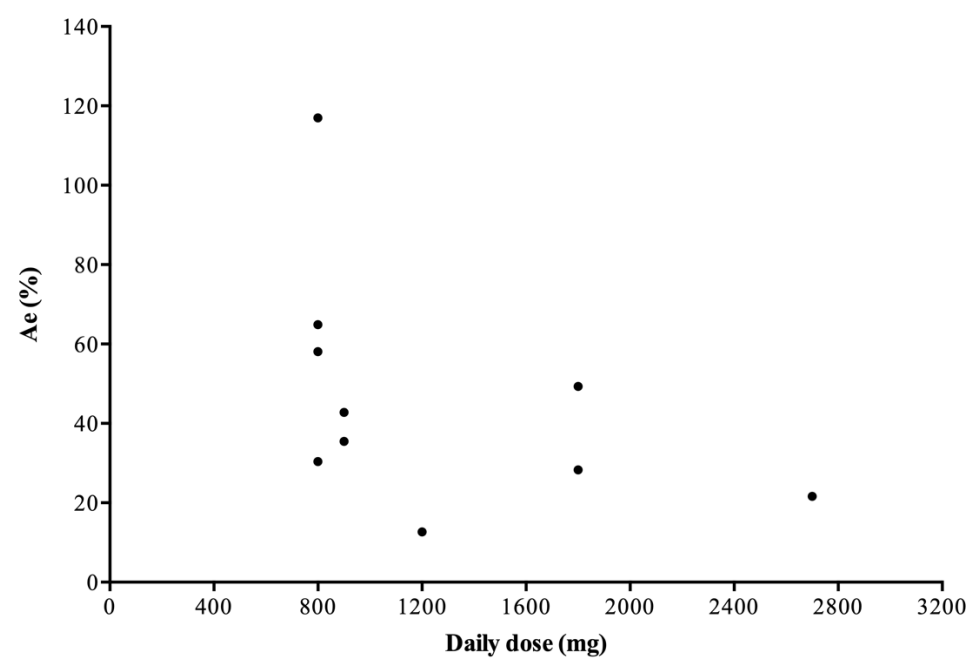

Figure 3. Applicability of the methods to quantify gabapentin in urine samples. Correlation between the amount of GAB eliminated unchanged in urine in the dose intervals (Ae \%) and daily dose (mg/day) $(n=10)$. [Ae $=$ urine concentration $\times$ urine total volume]

\section{DISCUSSION}

HPLC has been the most used method to analyze GAB concentration in biological samples. Other methods as gas chromatography and capillary electrophoresis were also developed, but in a small number ${ }^{25-28}$. Plasma is the most frequent sample used, few methods use other biological matrices, as urine $11,12,16,25$. This study presents a full validation results of bioanalytical methods to quantify GAB in plasma and urine using HPLC-UV.

As GAB does not have a chromophore group, a derivatization reaction was required. Different derivatizing agents have been used to react with GAB for ultraviolet detection, such as 4-nitrophenylisothiocyanate, 1,2-naphthoquinone-4-sulphonic acid sodium salt (NQS); 2,4,6-trinitrobenzene sulfonic acid (TNBSA) and 1-fluoro-2,4-dinitrobenzene (FDNB) ${ }^{11-15}$. According to the literature, the reaction with FDNB is faster (10 minutes) than using other agents. Although some methods using FDNB are published, sample stability was not described ${ }^{12,13}$. Our results showed that samples are stable up to $24 \mathrm{~h}$ after the derivatization. A limitation of this study was not evaluating the urine sample stability after being stored at $70{ }^{\circ} \mathrm{C}$ for a shorter period, since urine samples showed stability after 1 month at $-84{ }^{\circ} \mathrm{C}$ as reported by Yagi et al. ${ }^{16}$.

Many methods reported the recovery of GAB-derivatization agent complex $11,13,15,17,18,20,21$. However, the absolute recovery of GAB cannot be determined since no certificate standard of the product of derivatization is available ${ }^{29}$.

In classical pharmacokinetics studies, serial blood sampling is performed to obtain the plasma concentration versus time profile and pharmacokinetic parameters. Therefore, the use of small plasma volumes for the quantification of GAB is preferrable, since it requires small volumes of blood samples collected over time. The HPLC-UV method described in this study was validated using $200 \mu \mathrm{L}$ of plasma, which is smaller than the used in previous methods $(500 \mu \mathrm{L} \text { or } 1 \mathrm{~mL})^{11,13-15}$. Furthermore, sample preparations are simple (protein precipitation and liquid-liquid extraction for plasma and urine samples, respectively) and lower volume of organic solvents are used if compared to methods with solid-phase extraction or liquid phase microextraction ${ }^{11,12}$. 
HPLC and UHPLC coupled to tandem mass spectrometry detector (MS/MS) methods have also been described ${ }^{30-38}$. These methods have several advantages from the analytical chemical point of view. However, even with the advance of chromatography those methods require expensive instrumentation which may not be available in many hospitals. In terms of detectability, lower values of LLOQ are not required due to the high plasma concentrations of GAB observed after therapeutic doses for chronic pain treatment.

The LLOQ determined for GAB plasma quantification $(0.2 \mu \mathrm{g} / \mathrm{mL})$ in this study was higher than the described in previous methods. This could be a limitation only for pharmacokinetic studies with single dose and longer sampling time. However, our results showed that the concentration ranges were adequate to determinate GAB plasma and urine concentration in all patients undergoing chronic treatment.

In conclusion, this study describes HPLC-UV bioanalytical methods to quantify GAB in human plasma and urine. Sample preparation was rapid to perform using protein precipitation and liquid-liquid extraction as a clean-up technique for plasma and urine, respectively. Samples were derivatized with FDNB, in a quick reaction, and showed stability up to $24 \mathrm{~h}$ after preparation. The methods are simple, selective, precise, and accurate and were successfully applied to PopPK and TDM of GAB in patients with chronic pain.

\section{ACKNOWLEDGMENTS}

We thank Fabiola Dach for the support with the clinical protocol as principal investigators. The authors are grateful to the General Hospital of the Ribeirão Preto Medical School ( HCFMRP-USP) and Américo Brasiliense State Hospital (HEAB) for the access and support during the clinical protocol.

\section{REFERENCES}

1. Goldberg DS, McGee SJ. Pain as a global public health priority. BMC Public Health. 2011;11(1):770. http://dx.doi.org/10.1186/1471-2458-11-770. PMid:21978149.

2. Zelaya CE, Dahlhamer JM, Lucas JW, Connor EM. Chronic pain and high-impact chronic pain among U.S. adults, 2019. NCHS Data Brief, no 390. Hyattsville, MD: National Center for Health Statistics. 2020.

3. Vasconcelos FH, Araújo GC. Prevalence of chronic pain in Brazil: a descriptive study. Br J Pain. 2018;1:176-9.

4. Bennett DL. Informed drug choices for neuropathic pain. Lancet Neurol. 2015;14(2):129-30. http://dx.doi.org/10.1016/S1474-4422(14)70329-1. PMid:25575709.

5. Attal N, Cruccu G, Baron R, Haanpää M, Hansson P, Jensen TS, Nurmikko T, European Federation of Neurological Societies. EFNS guidelines on the pharmacological treatment of neuropathic pain: 2010 revision. Eur J Neurol. 2010;17(9):1113-e88. http://dx.doi.org/10.1111/j.14681331.2010.02999.x. PMid:20402746.

6. Bockbrader HN, Wesche D, Miller R, Chapel S, Janiczek N, Burger P. A comparison of the pharmacokinetics and pharmacodynamics of pregabalin and gabapentin. Clin Pharmacokinet. 2010;49(10):661-9. http://dx.doi.org/10.2165/11536200-000000000-00000. PMid:20818832.

7. Patsalos PN, Zugman M, Lake C, James A, Ratnaraj N, Sander JW. Serum protein binding of 25 antiepileptic drugs in a routine clinical setting: A comparison of free non-protein-bound concentrations. Epilepsia. 2017;58(7):1234-43. http://dx.doi.org/10.1111/epi.13802. PMid:28542801.

8. Bosilkovska M, Walder B, Besson M, Daali Y, Desmeules J. Analgesics in patients with hepatic impairment: pharmacology and clinical implications. Drugs. 2012;72(12):1645-69. http://dx.doi.org/10.2165/11635500-000000000-00000. PMid:22867045.

9. IQVIA Institute for Human Data Science. Medicine spending and affordability in the United States. Understanding patients' costs for medicines [Internet]. 2020 Aug. [cited 2020 Dec 15]. Available from: https://www.iqvia.com/insights/the-iqvia-institute/reports/medicine-spending-andaffordability-in-the-us

10. Finnerup NB, Attal N, Haroutounian S, McNicol E, Baron R, Dworkin RH, Gilron I, Haanpää M, Hansson P, Jensen TS, Kamerman PR, et al. Pharmacotherapy for neuropathic pain in adults: a 
systematic review and meta-analysis. Lancet Neurol. 2015;14(2):162-73. http://dx.doi.org/10.1016/S1474-4422(14)70251-0. PMid:25575710.

11. Sagirli O, Cetin SM, Onal A. Determination of gabapentin in human plasma and urine by highperformance liquid chromatography with UV-vis detection. J Pharm Biomed Anal. 2006;42(5):61824. http://dx.doi.org/10.1016/j.jpba.2006.05.012. PMid:16822634.

12. Ebrahimzadeh H, Yamini Y, Firozjaei HA, Kamarei F, Tavassoli N, Rouini MR. Hollow fiber-based liquid phase microextraction combined with high-performance liquid chromatography for the analysis of gabapentin in biological samples. Anal Chim Acta. 2010;665(2):221-6. http://dx.doi.org/10.1016/j.aca.2010.03.028. PMid:20417334.

13. Jalalizadeh $H$, Souri E, Tehrani MB, Jahangiri A. Validated HPLC method for the determination of gabapentin in human plasma using pre-column derivatization with 1-fluoro-2,4-dinitrobenzene and its application to a pharmacokinetic study. J Chromatogr B Analyt Technol Biomed Life Sci. 2007;854(1-2):43-7. http://dx.doi.org/10.1016/j.jchromb.2007.03.039. PMid:17517538.

14. Juenke JM, Brown PI, McMillin GA, Urry FM. Procedure for the monitoring of gabapentin with 2,4,6trinitrobenzene sulfonic acid derivatization followed by HPLC with ultraviolet detection. Clin Chem. 2003;49(7):1198-201.

15. Amini M, Rouini MR, Asad-Paskeh A, Shafiee A. A new pre-column derivatization method for determination of gabapentin in human serum by HPLC using UV detection. J Chromatogr Sci. 2010;48(5):358-61. http://dx.doi.org/10.1093/chromsci/48.5.358. PMid:20515528.

16. Yagi T, Naito T, Mino Y, Takashina Y, Umemura K, Kawakami J. Rapid and validated fluorometric HPLC method for determination of gabapentin in human plasma and urine for clinical application. J Clin Pharm Ther. 2012;37(1):89-94. http://dx.doi.org/10.1111/j.1365-2710.2010.01243.x. PMid:21276028.

17. Bahrami G, Kiani A. Sensitive high-performance liquid chromatographic quantitation of gabapentin in human serum using liquid-liquid extraction and pre-column derivatization with 9fluorenylmethyl chloroformate. J Chromatogr B Analyt Technol Biomed Life Sci. 2006;835(1-2):1236. http://dx.doi.org/10.1016/j.jchromb.2006.03.011. PMid:16574508.

18. Bahrami G, Mohammadi B. Sensitive microanalysis of gabapentin by high-performance liquid chromatography in human serum using pre-column derivatization with 4-chloro-7nitrobenzofurazan: application to a bioequivalence study. J Chromatogr B Analyt Technol Biomed Life Sci. 2006;837(1-2):24-8. http://dx.doi.org/10.1016/j.jchromb.2006.03.056. PMid:16644294.

19. Chung TC, Tai CT, Wu HL. Simple and sensitive liquid chromatographic method with fluorimetric detection for the analysis of gabapentin in human plasma. J Chromatogr A. 2006;1119(1-2):294-8. http://dx.doi.org/10.1016/j.chroma.2005.12.081. PMid:16426629.

20. Mercolini L, Mandrioli R, Amore M, Raggi MA. Simultaneous HPLC-F analysis of three recent antiepileptic drugs in human plasma. J Pharm Biomed Anal. 2010;53(1):62-7. http://dx.doi.org/10.1016/j.jpba.2010.02.036. PMid:20363577.

21. Martinc B, Roskar R, Grabnar I, Vovk T. Simultaneous determination of gabapentin, pregabalin, vigabatrin, and topiramate in plasma by HPLC with fluorescence detection. J Chromatogr B Analyt Technol Biomed Life Sci. 2014;962:82-8. http://dx.doi.org/10.1016/j.jchromb.2014.05.030. PMid:24907547.

22. European Medicines Agency. Guideline on Bioanalytical Method Validation [Internet]. London: Committee for Medicinal Product for Human Use (EMEA/CHMP/EWP/192217/2009); 2011 Jul. [cited 2020 Dec 15]. Available from: https://www.ema.europa.eu/en/documents/scientificguideline/guideline-bioanalytical-method-validation_en.pdf.

23. Yamamoto PA, Benzi JRL, Azeredo FJ, Dach F, lanhez Júnior E, Zanelli CF, de Moraes NV. Pharmacogenetics-based population pharmacokinetic analysis of gabapentin in patients with chronic pain: effect of OCT2 and OCTN1 gene polymorphisms. Basic Clin Pharmacol Toxicol. 2019;124(3):266-72. PMid:30192429.

24. Yamamoto PA, Benzi JRL, Dach F, de Moraes NV. Therapeutic drug monitoring of gabapentin: the applicability in patients with neuropathic pain. Braz J Pharm Sci. 2020

25. Lin X, Cai Y, Yan J, Zhang L, Wu D, Li H. Determination of Gabapentin in Human Plasma and Urine by Capillary Electrophoresis with Laser-Induced Fluorescence Detection. J Chromatogr Sci. 2015;53(6):986-92. http://dx.doi.org/10.1093/chromsci/bmu134. PMid:25352536.

26. Hlozek T, Bursova M, Coufal P, Cabala R. Gabapentin, Pregabalin and Vigabatrin Quantification in Human Serum by GC-MS After Hexyl Chloroformate Derivatization. J Anal Toxicol. 2016;40(9):74953. PMid:27590034. 
27. Borrey DC, Godderis KO, Engelrelst VI, Bernard DR, Langlois MR. Quantitative determination of vigabatrin and gabapentin in human serum by gas chromatography-mass spectrometry. Clin Chim Acta. 2005;354(1-2):147-51. http://dx.doi.org/10.1016/j.cccn.2004.11.023. PMid:15748611.

28. Ikeda K, Ikawa K, Yokoshige S, Yoshikawa S, Morikawa N. Gas chromatography-electron ionizationmass spectrometry quantitation of valproic acid and gabapentin, using dried plasma spots, for therapeutic drug monitoring in in-home medical care. Biomed Chromatogr. 2014;28(12):1756-62. http://dx.doi.org/10.1002/bmc.3217. PMid:24889681.

29. Peters FT, Maurer HH. Bioanalytical method validation and its implications for forensic and clinical toxicology - A review. Accredit Qual Assur. 2002;7(11):441-9. http://dx.doi.org/10.1007/s00769-0020516-5.

30. Park JH, Jhee OH, Park SH, Lee JS, Lee MH, Shaw LM, Kim KH, Lee JH, Kim YS, Kang JS. Validated LCMS/MS method for quantification of gabapentin in human plasma: application to pharmacokinetic and bioequivalence studies in Korean volunteers. Biomed Chromatogr. 2007;21(8):829-35. http://dx.doi.org/10.1002/bmc.826. PMid:17428017.

31. Wattananat T, Akarawut W. Validated LC-MS-MS method for the determination of gabapentin in human plasma: application to a bioequivalence study. J Chromatogr Sci. 2009;47(10):868-71. http://dx.doi.org/10.1093/chromsci/47.10.868. PMid:19930796.

32. Oertel R, Arenz N, Pietsch J, Kirch W. Simultaneous determination of three anticonvulsants using hydrophilic interaction LC-MS. J Sep Sci. 2009;32(2):238-43.

http://dx.doi.org/10.1002/jssc.200800461. PMid:19072899.

33. Juenke JM, Brown PI, Johnson-Davis KL, McMillin GA. Simultaneous quantification of levetiracetam and gabapentin in plasma by ultra-pressure liquid chromatography coupled with tandem mass spectrometry detection. Ther Drug Monit. 2011;33(2):209-13. http://dx.doi.org/10.1097/FTD.0b013e31820b1fce. PMid:21297550.

34. Kim KB, Seo KA, Kim SE, Bae SK, Kim DH, Shin JG. Simple and accurate quantitative analysis of ten antiepileptic drugs in human plasma by liquid chromatography/tandem mass spectrometry. J Pharm Biomed Anal. 2011;56(4):771-7. http://dx.doi.org/10.1016/j.jpba.2011.07.019. PMid:21840666.

35. Shibata M, Hashi S, Nakanishi H, Masuda S, Katsura T, Yano I. Detection of 22 antiepileptic drugs by ultra-performance liquid chromatography coupled with tandem mass spectrometry applicable to routine therapeutic drug monitoring. Biomed Chromatogr. 2012;26(12):1519-28. http://dx.doi.org/10.1002/bmc.2726. PMid:22383262.

36. Chahbouni A, Sinjewel A, G. den Burger JC, Vos RM, Wilhelm AJ, Veldkamp Al, Swart EL. Rapid quantification of gabapentin, pregabalin, and vigabatrin in human serum by ultraperformance liquid chromatography with mass-spectrometric detection. Ther Drug Monit. 2013;35(1):48-53. http://dx.doi.org/10.1097/FTD.0b013e31827788c0. PMid:23188183.

37. Nagaraju P, Kodali B, Datla PV, Kovvasu SP. LC-MS/MS Quantification of Tramadol and Gabapentin Utilizing Solid Phase Extraction. Int J Anal Chem. 2018;2018:1605950. http://dx.doi.org/10.1155/2018/1605950. PMid:30510578.

38. Palte MJ, Basu SS, Dahlin JL, Gencheva R, Mason D, Jarolim P, Petrides AK. Development and Validation of an Ultra-Performance Liquid Chromatography-Tandem Mass Spectrometry Method for the Concurrent Measurement of Gabapentin, Lamotrigine, Levetiracetam, Monohydroxy Derivative of Oxcarbazepine, and Zonisamide Concentrations in Serum in a Clinical Setting. Ther Drug Monit. 2018;40(4):469-76. http://dx.doi.org/10.1097/FTD.0000000000000516. PMid:29994986.

\section{Authors' contributions}

PAY - conceptualization, formal analysis, investigation, methodology, validation, visualization, writing - original draft, review \& editing; JRLB - investigation, methodology; NVM conceptualization, funding acquisition, project administration, resources, supervision, visualization, writing - original draft, review \& editing 